\title{
USER ACCEPTANCE OF ONLINE TRAVEL AGENTS FOR MILLENIALS AND GEN Z
}

\author{
Muhammad Faikar Thaufan Lubis ${ }^{1}$, Filda Rahmiati
}

\author{
${ }^{1}$ Management Study Progam, President University \\ Email: faikar.lubis19@gmail.com \\ ${ }^{2}$ Management Study Progam, President University \\ Faculty of Technology Management and Technopreneurship, Universiti Teknikal Malaysia Melaka \\ Email: filda.rahmiati@gmail.com
}

Masuk : 17-05-2019, revisi: 09-10-2019, diterima untuk diterbitkan : 30-10-2019

\begin{abstract}
ABSTRAK
Pariwisata adalah salah satu sektor yang berkontribusi paling besar terhadap perekonomian suatu negara. Selain itu, ia berkontribusi paling besar bagi pembangunan berkelanjutan seperti di Indonesia. Salah satu pemain pariwisata adalah agen perjalanan online yang melayani kebutuhan wisatawan sebelum bepergian. Karena itu, penting bagi agen perjalanan untuk memenuhi kebutuhan wisatawan. Tujuan dari penelitian ini adalah untuk menentukan penerimaan pengguna terhadap agen perjalanan online di Gen Z dan Millennials. Penelitian ini dilakukan untuk mempelajari model Unified Theory Acceptance dan Use of Technology 2 (UTAUT2). Populasi dari penelitian ini adalah semua orang yang pernah membeli tiket dan / atau memesan akomodasi di Agen Perjalanan Online menggunakan purposive sampling non-probabilitas. Penelitian ini mengumpulkan data dengan menyebarkan kuesioner elektronik (e-kuesioner). 200 responden memenuhi kriteria dalam penelitian ini. Untuk menganalisis data, Partial Least Square - Structural Equation Model (PLS-SEM) dianalisis menggunakan SmartPLS 3.2.8. Hasil penelitian ini menunjukkan bahwa Pengaruh Sosial, Motivasi Hedonik, dan Kebiasaan berpengaruh signifikan terhadap Behavioral Intention. Behavioral Intention juga memiliki pengaruh signifikan terhadap Use Behavior. Dalam efek moderasi, hanya Umur yang dapat memoderasi Pengaruh Sosial pada Niat Perilaku. Dengan demikian, direkomendasikan untuk penelitian selanjutnya untuk menggunakan model UTAUT2 yang lengkap dan menambahkan variabel Perceived Security. Di sisi lain, Pegipegi harus menambahkan lebih banyak layanan pada bisnis utama mereka.
\end{abstract}

Kata Kunci: UTAUT2, Agen Perjalanan Online, Penerimaan Teknologi, Niat Perilaku, Perilaku Penggunaan.

\begin{abstract}
Tourism is one of the sectors that contribute the most to a country's economy. Moreover, it contributes most to sustainable development such as in Indonesia. One of tourism players is an online travel agency that caters to the needs of tourists before travelling. Therefore, it is important for travel agents to meet the needs of tourists. The purpose of this study was to determine user acceptance of online travel agents in Gen $Z$ and Millennials. This research carried out to study Unified Theory Acceptance and Use of Technology 2 (UTAUT2) model. The population of this study is everyone who ever purchased ticket and/or booking accommodation on Online Travel Agent using non-probability purposive sampling. This research collected the data by spreading electronic questionnaire (e-questionnaire). 200 respondents met criteria in this research. To analyze the data, Partial Least Square - Structural Equation Model (PLS-SEM) analyzed using SmartPLS 3.2.8. The result of this research indicated that Social Influence, Hedonic Motivation, and Habit has significant influence on Behavioral Intention. Behavioral Intention also has significant influence on Use Behavior. In moderating effect, only Age can moderate Social Influence on Behavioral Intention. Thus, it is recommended for next research to use the complete of UTAUT2 model and add Perceived Security variable. On the other hand, Pegipegi should add more services on their main business.
\end{abstract}

Keywords: UTAUT2, Online Travel Agent, Technology Acceptance, Behavioural Intention, Use Behavior.

\section{INTRODUCTION Background}

Internet has been a crucial thing for helping human activities to make life easier, even can be called as primary needs. Nowadays Internet provides everything for human (Nofadhila et al., 
2018). Internet not only helps human in personal, but it also helps human in business. Buying products or using services now can be purchased through Internet. Additionally, the highest number of internet users are in age between 15 - 39 years old. According to Betz (2019), Millennials, also known as Generation Y, include anyone who were born between 1981 and 1996 (ages 23 to 38 in 2019). While Generation $Z$ defined as anyone who were born after 1997. Supported by Dimock (2019), Gen Z grew up with technology, the internet, and social media, which sometimes causes them to be stereotyped as tech-addicted. It can be stated that the highest internet users in Indonesia is Millenials and Gen Z.

Internet helped human for business activities. Travel (including accommodation) is the highest of total annual amount spent by USD 9.376 billion or increasing about 17\% (We Are Social, 2019). Thus, the percentage of consumers who plan to buy airplane tickets online and make hotel reservations and travel agents online is the most dominant, which shows that digital costumers prefer to fulfill their wants and needs in the tourism sector.

Tourism is one of the very large and rapidly growing economic sectors that fosters sustainable development in many countries. Tourism must be well managed so that it can provide benefits to the local community and the natural and cultural environment (Suryadinata et al., 2017). The development of Indonesian tourism from year to year continues to grow and even the competitiveness of Indonesia's tourism sector continues to increase. Accompanied by an increase in people's purchasing power and supported by sufficiently conducive security conditions, increase the number of tourist visits, especially the visit of Indonesian residents to travel in Indonesian territorial or commonly referred to as domestic tourist (Indonesia Statistics Bureau, 2019).

Thus, there is a fierce competition on online ticket reservation sites as facilitators of various online travel agent companies are starting to emerge, various services provided by online ticket reservation sites to help meet tourist needs are the existence of flight ticket reservation services, hotels, and trains. Shifting the way reservation through online sites, greatly facilitates tourists or prospective tourists in obtaining more choices of information on tourism products.

\section{Problem Identification}

There are several problems related to the acceptance and use of consumers to the technologies of Online Travel Agent application. Applications on smartphone both on Android and iOS experience frequent application create inconveniences of customer. Figure 4 shows there are several reasons for customer to use service on technology. Some problems occurred from customers feedback such as, an application error and bad of refund system and error in application while using the application for booking the service.

In this phenomenon, it is important looking on measure and evaluate the consumer acceptance use of technology, one of studies which will be used in this research is the Unified of Technology Acceptance and Use of Technology 2 (UTAUT2) model. The purpose of the UTAUT2 model is to identify three important variables of technology acceptance and use of technology for both the public and consumers, this model modify some of the relationships that already exist in the previous UTAUT model (Performance Expectancy, Effort Expectancy, Social Influence and Facilitating Condition) and introduce new relationships. Three new variables which added are Hedonic Motivation, Price Value, and Habit. Not only the new main variables, but also purposed moderating variable which are age, gender, and experience. 


\section{RESEARCH METHODOLOGY}

In this research, researcher applies Partial Least Square - Structural Equation Model (PLS-SEM) with quantitative approach. Quantitative approach is the approach that is done by recording and analyzing the data of research results exactly by using statistical calculation. Quantitative researchers seek explanations and predictions that will generate to other persons and places. Quantitative research involves collecting data so that information can be calculated and subjected to statistical treatment to support or reject the "alternative knowledge claims" (Creswell, 2014).

\section{Population and Sample}

The sampling technique used in this research is non-probability sampling with Purposive Sampling type. According to Sugiyono (2017) purposive sampling is techniques to determine the research sample with some specific considerations, criteria, or characteristics that aims to obtain data that can later be more presentative. According to Hair et al (2019), Sample size considerations is ten times the largest number of structural paths directed at a particular latent construct in the structural model. This study consists of 7 structural paths in total, so based on the sample size proposed by Hair, 7x10 or equal to minimum 70 samples is needed. It is better to round up to 100 respondents.

Characteristics or criteria set by the author for this study are Customer who ever purchased ticket and/or booked accommodation on one of biggest Online Travel Agent in Indonesia. Customers are aged Gen $\mathrm{Z}$ with min 17 years old and Millennials. Last, customers who are living in DKI Jakarta. According to APJII (2018) Java Island is the most contributed internet users based on region in Indonesia with 55.7\% of population in Indonesia. In Java Island, DKI Jakarta Province has the highest penetration of internet users with $80.4 \%$ of its residents. That is why in this research author used DKI Jakarta as sample region.

\section{Data Collection Method}

This study used primary data by questionnaire. In this study the questionnaire was distributed to customers who have access to use travel reservation from online travel agent. Measurement scale is an agreement that is used as a reference to determine the length of the short interval in the measuring instrument, so that the measuring tool when used in measurement will fill quantitative data (Sugiyono, 2017). With this measurement scale, the values of variables measured with certain instruments can be expressed in terms of numbers, so that it will be more accurate, efficient and communicative. The type of interval scale used in this study is a five Likert Scale.

\section{Data Analysis}

Activities in data analysis are grouping data based on variables and types of respondents, tabulating data based on variables from all respondents, presenting data for each variable studied, doing calculations to answer the problem formulation, and doing calculations to test hypotheses that have been proposed (Sugiyono, 2017).

According to Sandjojo (2011), Structural Equation Modeling (SEM) is a statistical technique for testing and estimating causal relationships using a statistical data with causal assumptions. Another definition states that Structural Equation Modeling (SEM) is a statistical modeling technique that is cross-sectional, linear, and general. A researcher is more likely to use SEM to determine whether a particular model is valid or not than to use it to find whether a particular model is suitable or not, although SEM analysis often includes elements used to explain (Sarwono \& Narimawati, 2015). This study uses SEM data analysis techniques with PLS-SEM 
types. PLS-SEM is a measurement model that shows how the observed variables represent the latent variables to be measured (Ghozali \& Latan, 2015).

PLS is characterized as the most suitable technique where the research objective is predictive or exploratory modeling. In general, covariance-based SEM is preferred when the research objective is confirmatory modeling (Garson, 2016). By using PLS-SEM an evaluation of the measurement model (outer model) analysis shows how the manifest variable represents the latent variable to be measured. Next, an analysis of the structural model (inner model) which shows the strength of the estimation between latent / construct variables. Evaluations of measurement models are grouped into evaluations of reflective and formative models. This study uses a reflective model in which measurement covariates are influenced by latent constructs (Ghozali \& Latan, 2015). In PLS-SEM to get a model that is fit or what can be called a pre-test, then this research tests the quality of the measurement model. To evaluate the goodness of fit of the outer measurement model, there are three requirements that must be considered, namely, convergent validity, discriminant validity, and reliability.

The rule of thumb for evaluate measurement model are:

1. Internal consistency reliability: Composite Reliability and Cronbach's Alpha > 0.70 (in exploratory research, 0.60-0.70 is still acceptable).

2. Convergent validity: AVE $\geq 0.50$ and Loading Factor $>0.70$

3. Discriminant validity: Cross-Loading and Fornell-Larcker Criterion must be the highest from other variables.

The rule of thumb for evaluation structural model are:

1. Internal consistency reliability: Composite Reliability and Cronbach's Alpha $>0.70$ (in exploratory research, 0.60-0.70 is still acceptable).

2. Convergent validity: AVE $\geq 0.50$ and Loading Factor $>0.70$

3. Discriminant validity: Cross-Loading and Fornell-Larcker Criterion must be the highest from other variables.

Testing the effects of moderation in SEM in the form of categories, such as age and gender, the moderating effect test is performed by comparison between groups or categories. In other words, to test the moderator variables in the form of categories is done by multigroup analysis (PLSMGA).

To test the influence of each of the moderate variables on the influence of independent variables to the dependent variable, multigroup analysis is done through the bootstrapping process with the help of SmartPLS which aims to improve the data analysis based on the sample characteristics with two or more data sets. Here are the steps to test the differences between sub-groups.

1. The sample data is divided by the moderator variable group

2. Calculates the path coefficient and standard error of each group by bootstrapping method in SmartPLS application

3. Comparing the differences between the path coefficient and standard errors of each group using Smith-Satterthwait test explained by Chin (2000)

\section{Hypotheses Testing}

The calculation in this study compares the t-value calculated by t-Table, where the alternative hypothesis will be accepted if the calculated $t$ value is greater than $t$ Table. Hypothesis testing is done partially by calculating the value of $t$ through the help of SmartPLS 3.2.8. The $t$ distribution 
Table is at $\alpha=5 \%$. For decision criteria, hypothesis testing in this research is using two-tailed test because of hypothesis testing with UTAUT 2 constructs are likely to have a significant influence or not. The critical value that must be met is t-table of 1.96. That is, if the value of $t$ table is greater than 1.96, then there is a significant positive between the exogenous latent construct and the endogenous latent construct tested.

The following are hypotheses testing in this study:

1. The influence of Performance Expectancy (PE) on Behavioral Intention (BI)

$\mathrm{H}_{1} \quad$ : Performance Expectancy has significant influence on Behavioral Intention

H1a : Performance Expectancy is moderated by age on Behavioral Intention

$\mathrm{H} 1 \mathrm{~b}$ : Performance Expectancy is moderated by gender on Behavioral Intention Intention

2. The Influence of Effort Expectancy (EE) on Behavioral Intention (BI)

$\mathrm{H} 2$ : Effort Expectancy has significant influence on Behavioral Intention.

$\mathrm{H} 2 \mathrm{a}$ : Effort Expectancy is moderated by age on Behavioral Intention

$\mathrm{H} 2 \mathrm{~b}$ : Effort Expectancy is moderated by gender on Behavioral Intention

3. The Influence of Social Influence (SI) on Behavioral Intention (BI)

H3 : Social Influence has significant influence on Behavioral Intention.

$\mathrm{H} 3 \mathrm{a}$ : Social Influence is moderated by age on Behavioral Intention.

$\mathrm{H} 3 \mathrm{~b}$ : Social Influence is moderated by gender on Behavioral Intention.

4. The Influence of Facilitating Conditions (FC) on Behavioral Intention (BI)

H4 : Facilitating Condition has significant influence on Behavioral Intention.

$\mathrm{H} 4 \mathrm{a}$ : Facilitating Condition is moderated by age on Behavioral Intention.

$\mathrm{H} 4 \mathrm{~b}$ : Facilitating Condition is moderated by gender on Behavioral Intention.

5. The Influence of Hedonic Motivation (HM) on Behavioral Intention (BI)

H5 : Hedonic Motivation has significant influence on Behavioral Intention.

H5a : Hedonic Motivation is moderated by age on Behavioral Intention.

$\mathrm{H} 5 \mathrm{~b}$ : Hedonic Motivation is moderated by gender on Behavioral Intention

6. The Influence of Habit $(\mathrm{H})$ on Behavioral Intention (BI)

H6 : Habit has significant influence on Behavioral Intention.

H6a : Habit is moderated by age on Behavioral Intention

$\mathrm{H} 6 \mathrm{~b}$ : Habit is moderated by gender on Behavioral Intention

7. The Influence of Behavioral Intention (BI) on Use Behavior (UB)

H7 : Behavioral Intention has significant influence on Use Behavior. 


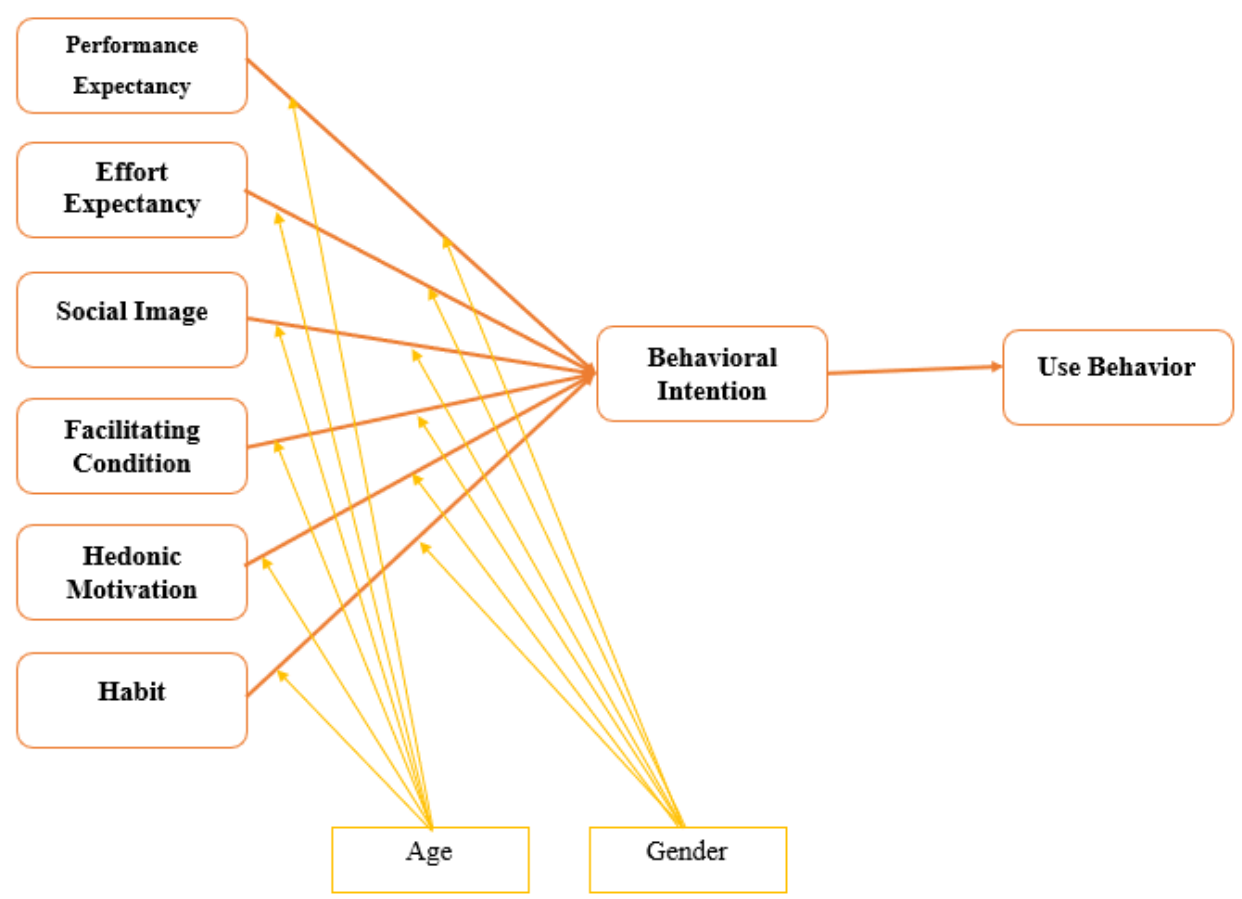

Figure 1: Theoretical Framework

Source: Modified by Author Adapted from Venkatesh et al. (2012)

\section{RESULT AND DISCUSSION}

After screening questions, researcher deleted respondents who are not met the criteria of this research and got 200 valid respondents out of 250 respondents, thus 200 data will use for further analysis. Characteristics of the respondents were $49 \%$ of Millenials and $51 \%$ for Gen $\mathrm{Z}$ with gender of $55 \%$ females and $45 \%$ were males. Services used by respondents were show in Figure 2 below.

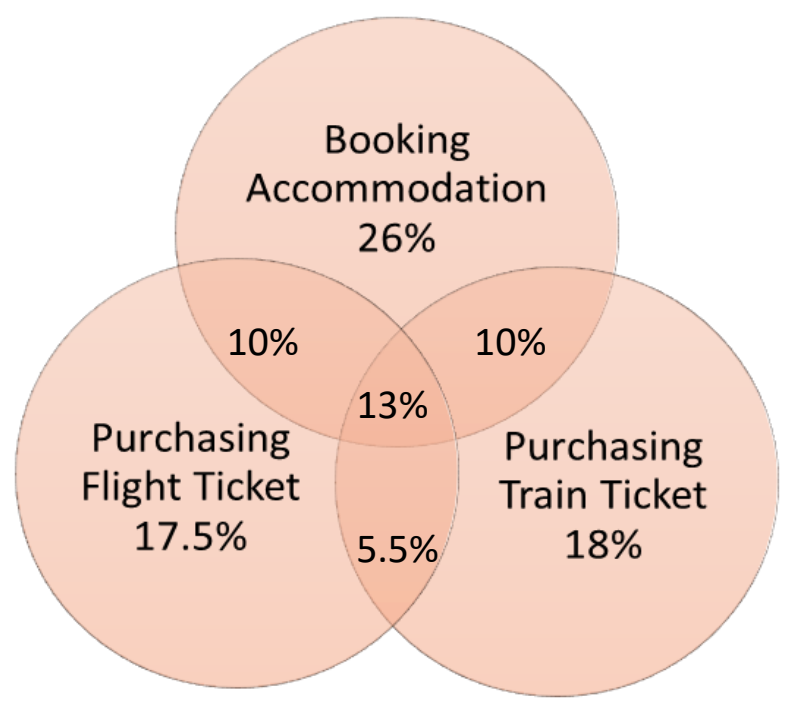

Figure 2: Respondent Characteristics by Service

\section{Analysis of SEM}

The analytical analysis in this study use Structural Equation Model with Partial Least Square approach and the help of software SmartPLS 3.2.8 (Ringle et al., 2015). PLS-SEM analysis 
usually consists of two sub models, those are measurement models or often called as Measurement models and structural models.

\section{Measurement Model Result}

Based on Figure 1, the result of convergent validity show that the value of all items has a loading factor value greater than 0.5 . It can be concluded that all indicators of the variable constructs of Performance Expectancy, Effort Expectancy, Social Influence, Facilitating Conditions, Hedonic Motivation, Habit, Behavioral Intention and Use Behavior are valid. The value of AVE in each latent variable is greater than 0.5 , which means each variable can explain $50 \%$ or more on its item. It also declared as valid and meets the criteria of convergent validity show in Table 1.

Table 1: AVE Result

\begin{tabular}{|l|l|l|}
\hline Latent Variable & AVE Result & Conclusion \\
\hline Performance Expectancy (PE) & 0.672 & Valid \\
\hline Effort Expectancy (EE) & 0.735 & Valid \\
\hline Social Influence (SI) & 0.839 & Valid \\
\hline Facilitating Condition (FC) & 0.626 & Valid \\
\hline Hedonic Motivation (HM) & 0.810 & Valid \\
\hline Habit (H) & 0.869 & Valid \\
\hline Behavioral Intention (BI) & 0.865 & Valid \\
\hline Use Behavior (UB) & 0.749 & Valid \\
\hline
\end{tabular}

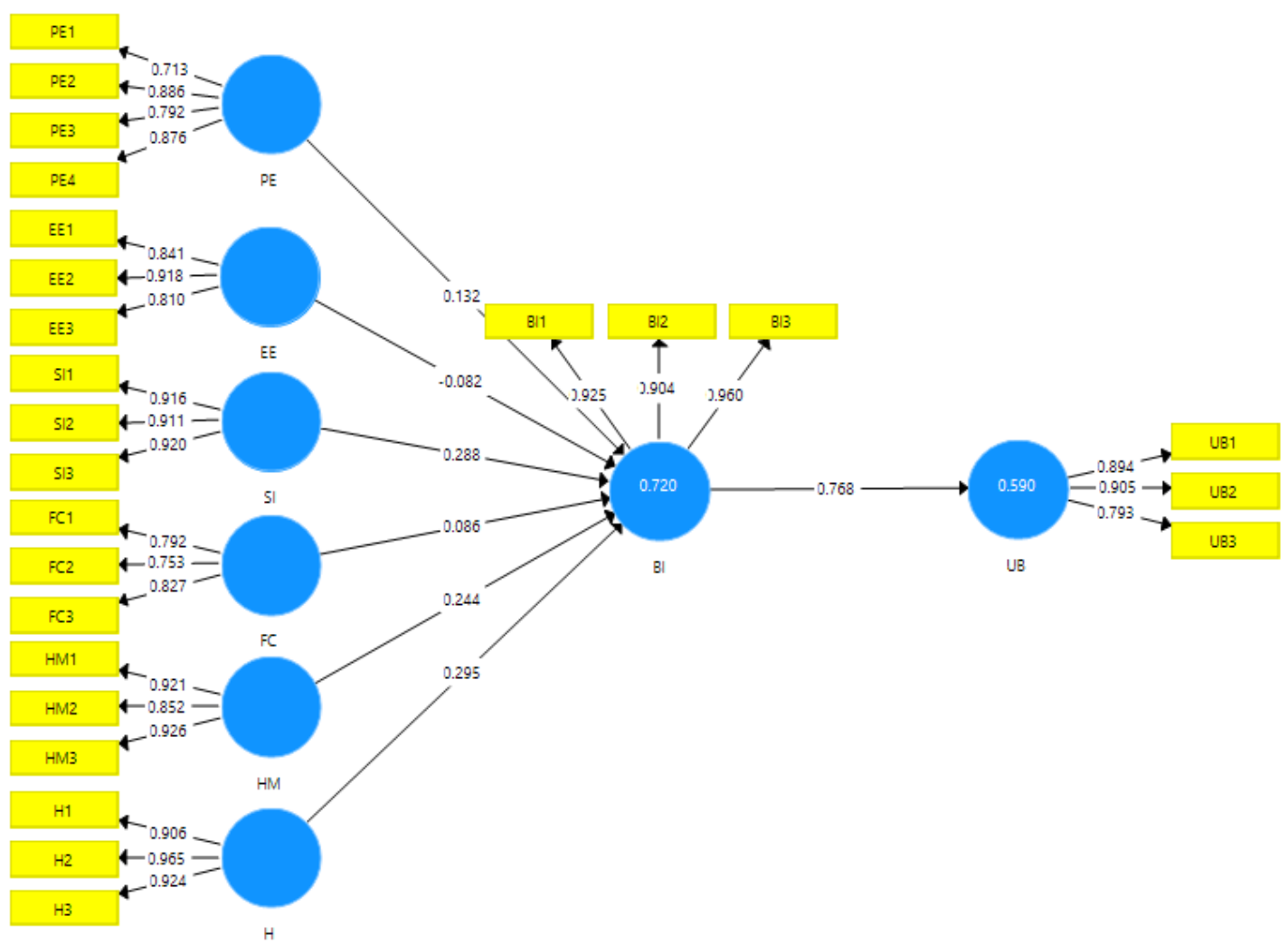

Figure 3: Loading Factors Result

To test whether the reflective indicator is really good measurement of its construct based on the principle that each indicator must be highly correlated to its construct (Ghozali \& Latan, 2015). This discriminant validity use value of cross-loading and Fornell-Larcker criterion. The value of cross loading of all indicators on its own construct has a greater value than the loading factor of the indicator in other constructs. It is concluded that the all unrelated constructs are not related 
and meet discriminant validity criteria. The results of discriminant validity of each latent variable can be seen in Table 3, the results Fornell-Larcker met the criterian, then all latent variables in this study are declared to meet the requirements of discriminant validity. Based on Table 4, the value of Construct Reliability (CA and CR) of each variable is greater than 0.7 . Thus, it can be concluded that all variables are considered reliable to be included in hypothesis testing.

Table 3: Fornell-Larcker Criterion Result

\begin{tabular}{|l|l|l|l|l|l|l|l|l|}
\hline & BI & EE & FC & H & HM & PE & SI & UB \\
\hline BI & 0.930 & & & & & & & \\
\hline EE & 0.458 & 0.857 & & & & & & \\
\hline FC & 0.607 & 0.731 & 0.791 & & & & & \\
\hline H & 0.761 & 0.493 & 0.619 & 0.932 & & & & \\
\hline HM & 0.756 & 0.584 & 0.668 & 0.689 & 0.900 & & & \\
\hline PE & 0.582 & 0.753 & 0.693 & 0.505 & 0.710 & 0.820 & & \\
\hline SI & 0.762 & 0.313 & 0.501 & 0.756 & 0.712 & 0.452 & 0.916 & \\
\hline UB & 0.768 & 0.544 & 0.673 & 0.818 & 0.760 & 0.624 & 0.723 & 0.865 \\
\hline
\end{tabular}

Table 4: Construct Reliability

\begin{tabular}{|l|l|l|l|}
\hline Variable & Cronbach's Alpha (CA) & Composite Reliability (CR) & Conclusion \\
\hline Performance Expectancy & 0.835 & 0.891 & Reliable \\
\hline Effort Expectancy & 0.819 & 0.892 & Reliable \\
\hline Social Influence & 0.904 & 0.940 & Reliable \\
\hline Facilitating Condition & 0.709 & 0.834 & Reliable \\
\hline Hedonic Motivation & 0.882 & 0.927 & Reliable \\
\hline Habit & 0.924 & 0.952 & Reliable \\
\hline Behavioral Intention & 0.922 & 0.950 & Reliable \\
\hline Use Behavior & 0.830 & 0.899 & Reliable \\
\hline
\end{tabular}

\section{Structural Model Result}

Table 5 shown that the R-square value for each dependent variable (endogenous latent variable). The R-square value for the endogenous variables of Behavioral Intention is 0.72, meaning the percentage of Behavioral Intention which can be explained by Performance Expectancy, Effort Expectancy, Social Influence, Facilitating Conditions, and Habit is $72 \%$ and the rest $28 \%$ is explained by other variables that did not examined in this study. This R-square value shows that the model belongs to a strong classification. While the R-square for the endogenous variable of Use Behavior is 0.59 , meaning the percentage of Use Behavior which can be explained by Behavioral Intention is $59 \%$ and the rest $41 \%$ is explained by other variables that did not examined in this study. This $\mathrm{R}$-square value shows that the model belongs to a substantial classification. Table 6 shows $\mathrm{Q}^{2}$ on Behavioral Intention shows 0.577 and $\mathrm{Q}^{2}$ on Use Behavior shows 0.416. Both variables show value more than 0 means this research has predictive relevance.

Table 5: Determinant Coefficient Result

\begin{tabular}{|l|l|l|}
\hline Dependent Variable & R-square & Conclusion \\
\hline Behavioral Intention & 0.72 & Substantial \\
\hline Use Behavior & 0.59 & Moderate \\
\hline
\end{tabular}

Table 6: Predictive Relevance Result

\begin{tabular}{|l|l|l|l|}
\hline & SSO & SSE & $\mathbf{Q}^{2}(=1-$-SSE/SSO $)$ \\
\hline BI & 600.000 & 253.594 & 0.577 \\
\hline
\end{tabular}




\begin{tabular}{|l|l|l|l|} 
EE & 600.000 & 600.000 & \\
\hline FC & 600.000 & 600.000 & \\
\hline H & 600.000 & 600.000 & \\
\hline HM & 600.000 & 600.000 & \\
\hline PE & 800.000 & 800.000 & \\
\hline SI & 600.000 & 600.000 & \\
\hline UB & 600.000 & 350.310 & 0.416 \\
\hline
\end{tabular}

\section{Hypothesis Testing}

The t-value test is intended to test the influence of independent variables (exogenous latent variables) and dependent variables (endogenous latent variables). T-value in each exogenous latent variable to endogenous latent variables is obtained from the bootstrapping process using SmartPLS 3.2.8. The path coefficient diagram of inner model after bootstrapping in this research can be seen in Figure 4. The result of t-value is summarized in Table 7.

Table 7: Hypothesis Result

\begin{tabular}{|c|c|c|c|}
\hline No & Hypothesis & Result & Conclusion \\
\hline $\mathrm{H} 1$ & $\begin{array}{l}\text { Performance Expectancy has significant influence on } \\
\text { Behavioral Intention }\end{array}$ & Not Significant & Rejected \\
\hline $\mathrm{H} 1 \mathrm{a}$ & $\begin{array}{l}\text { Performance Expectancy is moderated by age on } \\
\text { Behavioral Intention }\end{array}$ & Unsupported & Rejected \\
\hline $\mathrm{H} 1 \mathrm{~b}$ & $\begin{array}{l}\text { Performance Expectancy is moderated by gender on } \\
\text { Behavioral Intention. }\end{array}$ & Unsupported & Rejected \\
\hline $\mathrm{H} 2$ & $\begin{array}{l}\text { Effort Expectancy has significant influence on } \\
\text { Behavioral Intention }\end{array}$ & Not Significant & Rejected \\
\hline $\mathrm{H} 2 \mathrm{a}$ & $\begin{array}{l}\text { Effort Expectancy is moderated by age on Behavioral } \\
\text { Intention }\end{array}$ & Unsupported & Rejected \\
\hline $\mathrm{H} 2 \mathrm{~b}$ & $\begin{array}{l}\text { Effort Expectancy is moderated by gender on } \\
\text { Behavioral Intention }\end{array}$ & Unsupported & Rejected \\
\hline $\mathrm{H} 3$ & $\begin{array}{l}\text { Social Influence has significant influence on } \\
\text { Behavioral Intention. }\end{array}$ & Significant & Accepted \\
\hline $\mathrm{H} 3 \mathrm{a}$ & $\begin{array}{l}\text { Social Influence is moderated by age on Behavioral } \\
\text { Intention. }\end{array}$ & Moderated & Accepted \\
\hline $\mathrm{H} 3 \mathrm{~b}$ & $\begin{array}{l}\text { Social Influence is moderated by gender on Behavioral } \\
\text { Intention }\end{array}$ & Not Moderated & Rejected \\
\hline $\mathrm{H} 4$ & $\begin{array}{l}\text { Facilitating Condition has significant influence on } \\
\text { Behavioral Intention. }\end{array}$ & Not Significant & Rejected \\
\hline $\mathrm{H} 4 \mathrm{a}$ & $\begin{array}{l}\text { Facilitating Condition is moderated by age on } \\
\text { Behavioral Intention. }\end{array}$ & Unsupported & Rejected \\
\hline $\mathrm{H} 4 \mathrm{~b}$ & $\begin{array}{l}\text { Facilitating Condition is moderated by gender on } \\
\text { Behavioral Intention. }\end{array}$ & Unsupported & Rejected \\
\hline H5 & $\begin{array}{l}\text { Hedonic Motivation has significant influence on } \\
\text { Behavioral Intention. }\end{array}$ & Significant & Accepted \\
\hline H5a & $\begin{array}{l}\text { Hedonic Motivation is moderated by age on Behavioral } \\
\text { Intention. }\end{array}$ & Not Moderated & Rejected \\
\hline $\mathrm{H} 5 \mathrm{~b}$ & $\begin{array}{l}\text { Hedonic Motivation is moderated by gender on } \\
\text { Behavioral Intention }\end{array}$ & Not Moderated & Rejected \\
\hline H6 & Habit has significant influence on Behavioral Intention & Significant & Accepted \\
\hline
\end{tabular}




\begin{tabular}{|l|l|l|l|}
\hline H6a & Habit is moderated by age on Behavioral Intention & Not Moderated & Rejected \\
\hline H6b & Habit is moderated by gender on Behavioral Intention & Not Moderated & Rejected \\
\hline H7 & $\begin{array}{l}\text { Behavioral Intention has significant influence on Use } \\
\text { Behavior }\end{array}$ & Significant & Accepted \\
\hline
\end{tabular}

\section{Discussion}

The Influence of Performance Expectancy on Behavioral Intention

Based on the results of statistical analysis, Performance Expectancy (H1) has a t-statistic value of 1.48 which is less than the t-table which is 1.96 and makes Ho accepcted and Ha rejected. Thus, it can be concluded that Performance Expectancy has not significantly affects the Behavioral Intention of customer. The result is not relevant with result of technology adoption research which have been done with first research before by Venkatesh et al. (2003). Supported with previous research by Hikmah et al., (2018); Liu \& Huang (2015); Malau (2016); Putra (2018). This result is likely due to customers still not optimal in utilizing the use of the system. This pnline travel agent is not a system or application that plays a direct role in their activities, especially in terms of transactions. Customers will not be interested in using Pegipegi even though in the future they will benefit greatly from using the system. A system will feel a great benefit if the system provides significant benefits to system users (Rema \& Setyohadi, 2016).

The Influence of Effort Expectancy on Behavioral Intention

Based on the results of statistical analysis, Effort Expectancy (H2) has a t-statistic value of 0.959 that is below the t-table which is 1.96 and makes Effort Expectancy has no positive and significant influence on the Behavioral Intention The result is consistent with result of technology adoption research which have been done before by Gupta \& Dogra (2017); Morgan (2013); Nofadhila (2018); Putra (2018); Marhaeni (2014); Melisa \& Indrawati (2016) that resulted Effort Expectancy does not have positive influence on Behavioral Intention. By looking at the profile of respondents in this study, 51\% of respondents' age in range of 17-22 years old which included in the category of Gen Z. In adoption theory, this age occupies in early adoption and innovators group. It means the people try and adopt technologies that provide solutions and support services needed. To achieve this, the aspect of ease is no longer a consideration.

The Influence of Social Influence on Behavioral Intention

Based on the results of statistical analysis, Social Influence (H3) has a t-statistic value of 3.016 that is greater than the t-table which is 1.96 and makes Social Influence does has significant influence on the Behavioral Intention. The result of hypothesis is similar with result by Putra (2018); Venkatesh et al. (2003, 2012) states that the influence of social influence is proven significant to the behavioral intention. This finding means important people, influential people or the number of people using this online travel agent could give influence. With the growing number of users, it may be influenced by people around the user and also from other factors such as ads, promos, discounts, and other marketing programs.

The Influence of Facilitating Conditions on Behavioral Intention

Based on the results of statistical analysis, Facilitating Conditions (H4) has a t-statistic value of 0.959 that is lower than the t-table which is 1.96 and makes Facilitating Conditions has no significant influence on the Behavioral Intention. The result of hypothesis testing which states that Facilitating Conditions do not significant influence Behavioral Intention is consistent with the result of mobile commerce adoption research which have been done previously by Jaradat \& Al Rababaa (2013); Kamal \& Azis (2015); Nofadhila et al. (2018); Putra (2018); Ramdhani et al., (2017). A possible explanation of this finding is that the respondents from this study were 
dominated by Gen $\mathrm{Z}$ groups who also dominated the use of internet and smartphones, believed that the infrastructure such as smartphones and internet are needed.

The Influence of Hedonic Motivation on Behavioral Intention

Based on the results of statistical analysis, Hedonic Motivation (H5) has a t-statistic value of 2.585 that is greater than the t-table which is 1.96 and makes Hedonic Motivation has significant influence on the Behavioral Intention. The results of this study are in line with Auliya (2018); Putra (2018); Venkatesh et al. (2012). This result is due to the Hedonic Motivation has significant influence the acceptance and use of technology so that people feel the fun or pleasure in using e-tickets derived from the use of technology, and have proven to play an important role in determining the adoption and use of technology (Pertiwi \& Ariyanto, 2017). This finding means the fun, enjoyment and entertainment increase the customer behavioral in using it. This may also be because this application and web which included in interesting category, so fun, enjoyment and entertaining are one of its strategy to attract customer to use.

The Influence of Habit on Behavioral Intention

Based on the results of statistical analysis, Habit (H6) has a t-statistic value of 3.124 that is greater than the t-table which is 1.96 and makes Habit does has significant influence on the Behavioral Intention. The result is consistent with result of technology adoption researches which have been done previously by Venkatesh et al. (2012) that states Habit has positive and significant influence on Behavioral Intention not only the main relationships from UTAUT, but also new constructs and relationships that extend the applicability of UTAUT to the consumer context. Research from Hew et al., (2015) result has been confirmed as the most significant driver Behavioral Intention in mobile app usage and research result by Marhaeni (2014) shows Habit significantly influence Behavioral Intention in using instant messenger applications.

The Influence Behavioral Intention on Use Behavior

Based on the results of statistical analysis, Behavioral Intention (H7) has a t-statistic value of 15.696 that is greater than the t-table which is 1.96 and makes Behavioral Intention significantly influence Use Behavior. The result is consistent with result of Venkatesh et al. (2012) that states Behavioral Intention has positive and significant influence on Use Behavior not only the main relationships from UTAUT, but also new constructs and relationships that extend the applicability of UTAUT to the consumer context. Research from Tak \& Panwar (2017) result stated Behavioral Intention and significantly influence Use Behavior on mobile apps-based shopping and research result by Marhaeni (2014) shows Behavioral Intention has positive and significant influence on Use Behavior in using instant messenger applications.

The Influence of Moderate Variable "Gender"

In this study found that Gender did not moderate the influence of all significance independent variables. The results are consistent with the results of the research Hew et al. (2015) which states that Gender does not moderate all paths to the mobile app usage intention. Hence, it is irrelevant with Goswami \& Dutta (2016) who states that Gender has been observed from the review that in few contexts, Gender plays a significant role in determining the intention of accepting new technology and there are cases where gender differences cannot be discerned.

The Influence of Moderate Variable "Age"

In this study, the author found that Age only moderates Social Influence on Behavioral Intention. It shows that there are significant differences between respondents Gen $\mathrm{Z}$ with Gen $\mathrm{Y}$ in response to Social Influence on Behavioral Intention. Social Influence is someone's awareness 
about someone else using a system. These results are in accordance with the results of the study of Venkatesh et al. (2003) who found social influence on the desire to use the system tended to strengthen towards older users. But the results were also found in Nofadhila et al. (2018); Yu, (2012) study which showed that younger users were more socially affected than older users.

\section{CONCLUSION AND RECOMMENDATION \\ Conclusion}

Based on UTAUT2 modification model, the variables affecting Behavioral Intention in adopting and using Pegipegi by users in Indonesia are Social Influence, Hedonic Motivation and Habit, while other three variables have not significant influence on Behavioral Intention. Based on the result of this study, it shows that Behavioral Intention have significant influence on Use Behavior, which means it affect the Use Behavior in using Pegipegi in Jakarta. Age proved to moderate the influence of Social Influence on Behavioral Intention in adopting and using Pegipegi in Jakarta.

\section{Recommendation}

Further research should be able to conduct research that is included Price Value as the independent variable to predict the Behavioral Intention. Additionally, it would be nice for further research to expand the research area in other regions in Indonesia or even in other countries, especially for the international tourist who ever come to Indonesia

\section{Acknowledgement}

Researchers would like to thank the Department of Research and Community Development of President University for the support given in the form of research funding assistance that supports this research well.

\section{REFERENCE}

Auliya, N. (2018). Application of the Unified Theory of Acceptance and Use of Technology 2 Model to the Interest and Behavior of E-Ticket Use in Yogyakarta.

Betz, C. L. (2019). Generations X, Y, and Z. Journal of Pediatric Nursing, 44, A7-A8. https://doi.org/10.1016/j.pedn.2018.12.013

Chin, W. W. (2000). Frequently Asked Questions - Partial Least Squares \& PLS-Graph. Retrieved December 14, 2019, from http://disc-nt.cba.uh.edu/chin/plsfaq.htm

Creswell, J. W. (2014). Research Design: Qualitative, Quantitative, and Mixed Methods Approaches (4th Edition). Callifornia: SAGE Publications, Inc.

Dimock, M. (2019). Defining generations: Where Millennials end and Generation Z begins. Retrieved December 15, 2019, from Pew Research Center website: https://www.pewresearch.org/fact-tank/2019/01/17/where-millennials-end-andgeneration-z-begins/

Garson, G. D. (2016). Partial Least Squares: Regression \& Structural Equation Models. In G. David Garson and Statistical Associates Publishing. North Carolina: Stastical Associates Publishing.

Ghozali, I., \& Latan, H. (2015). Partial Least Squares Concepts, Techniques and Applications using the SmartPLS 3.0 Program (Edition 2). Semarang: Publisher Agency - Undip.

Goswami, A., \& Dutta, S. (2016). Gender differences in schizophrenia: A literature review. Journal of Business and Management, 3(4), 51-59. https://doi.org/10.3109.10401239109148015

Gupta, A., \& Dogra, N. (2017). Tourist adoption of mapping apps: A UTAUT2 perspective of smart travellers. Tourism and Hospitality Management, 23(2), 145-161. 
https://doi.org/10.20867/thm.23.2.6

Hair, J. F., Risher, J. J., Sarstedt, M., \& Ringle, C. M. (2019). When to use and how to report the results of PLS-SEM. European Business Review, 31(1), 2-24. https://doi.org/10.1108/EBR-11-2018-0203

Hew, J.-J., Lee, V.-H., Ooi, K.-B., \& Wei, J. (2015). What catalyses mobile apps usage intention: An empirical analysis. Industrial Management \& Data Systems, 115(7), 1269 1291. https://doi.org/https://doi.org/10.1108/IMDS-01-2015-0028

Hikmah, A. F., Kusyanti, A., \& Perdanakusuma, A. R. (2018). Analysis of Factors Affecting ABC Messenger User Behavior in Receiving Information at XYZ Institution by Using The Unified Theory of Acceptance and Use of Technology (UTAUT). 2 (4), 1372-1381.

Indonesia Statistics Bureau (2019). Domestic Tourist Statistic 2018. Retrieved from https://www.bps.go.id/publication/2019/07/02/5249c2b645e21291b51dfc1a/statistikwisatawan-nusantara-2018.html

Jaradat, M.-I. R. M., \& Al Rababaa, M. S. (2013). Assessing Key Factor that Influence on the Acceptance of Mobile Commerce Based on Modified UTAUT. International Journal of Business and Management, 8(23), 102-112. https://doi.org/10.5539/ijbm.v8n23p102

Kamal, R. M., \& Azis, E. (2015). Adoption of Internet Technology by Indonesian MSME Consumers to Shop Online (Study on the site Tokopedia.com 2015). 2 (3), 2451-2458.

Liu, Y. C., \& Huang, Y. M. (2015). Using the UTAUT model to examine the acceptance behavior of synchronous collaboration to support peer translation. JALT CALL Journal, 11(1), 77-91.

Malau, Y. (2016). Analysis of Rail Ticket System Acceptance at PT. KAI using the UTAUT model. Paradigm, XVIII (2), 102-112.

Marhaeni, G. A. M. M. (2014). Analysis of the Behavior of Using Instant Messaging Applications using the Unified Theory of Acceptance and Use of Technology 2 Model in Bandung. E-Proceeding of Management, 1 (3), 42-56.

Melisa, \& Indrawati. (2016). Analysis of Customer Acceptance of Online Travel Agent Technology using UTAUT2 Model (A Case Studt on E-Commerce Traveloka in Indonesia). Sustainable Collaboration in Business, Technology, Information and Innovation, 7(2012), 115-120.

Morgan, A. R. (2013). Factors Influencing Student Use of Online Homework Management Systems. Research Gate Annual Edition, 3, 98-112.

Nofadhila, A., Prasetio, A., \& Sofyan, E. (2018). The Consumer Acceptance of Traveloka Mobile App Affects Behavioral Intention: Analyzing 7 Factors of Modified UTAUT2 (Study Case in Indonesia). E-Proceeding of Management, 5(1), 874.

Pertiwi, N. W. D. M. Y., \& Ariyanto, D. (2017). Penerapan Model UTAUT2 untuk Menjelaskan Minat dan Perilaku Penggunaan Mobile Banking di Kota Denpasar. E-Jurnal Akuntansi Universitas Udayana, 18(2), 1369-1397. https://doi.org/10.1017/CBO9781107415324.004

PJII. (2018). Penetration \& Profile of Indonesian Internet User Behavior. In Apjii. Retrieved from www.apjii.or.id

Putra, M. A. A. (2018). Evaluation of Use of Bank Mandiri E-Money Electronic Money Products Using the UTAUT 2 Model (Case Study: Ciputat District) (Vol. 2). Syarif Hidayatullah State Islamic University Jakarta.

Ramdhani, A. B., Rachmawati, I., Sidiq, F., \& Prabowo, A. (2017). Effect of Adoption of Telkomsel Cash Electronic Money Service Technology Using the Utaut Approach2 The Effect of Adoption Technology Electronic Money Services Telkomsel Cash Using Utaut2. E-Proceeding of Management, 4 (1), 53-61.

Rema, Y. O. L., \& Setyohadi, D. B. (2016). Factors affecting the acceptance of mobile banking 
case studies: BRI Bajawa Branch. Information Technology Research Seminar, 114-122.

Ringle, C. M., Wende, S., \& Becker, J.-M. (2015). SmartPLS 3. Retrieved from http://www.smartpls.com

Sandjojo, N. (2011). Path Analysis Method and its Application. Jakarta: Pustaka Sinar Harapan.

Sarwono, J., \& Narimawati, U. (2015). Make a Thesis, Thesis, and Dissertation with Partial Least Square (PLS SEM). Yogyakarta: ANDI Publisher.

Sugiyono (2017). Quantitative, Qualitative, and R\&D Research Methods. Bandung: Alfabeta.

Suryadinata, A. S., Ariyanti, M., \& Sumrahadi. (2017). Positioning Analysis of Online Ticket Reservation Sites Based on Consumer Perceptions in Indonesia in 2016 (Study on Traveloka Sites, Tickets, Tiket2, Pegipegi, and Nusatrip). E-Proceeding of Management, 4 (2), 1188-1195.

Tak, P., \& Panwar, S. (2017). Using UTAUT 2 model to predict mobile app based shopping: evidences from India. Journal of Indian Business Research, 9(3), 248-264. https://doi.org/10.1108/JIBR-11-2016-0132

Venkatesh, V., Thong, J. Y. L., \& Xu, X. (2012). Consumer acceptance and use of information technology: Extending the unified theory of acceptance and use of technology. MIS Quarterly, 36(1), 157-178.

We Are Social. (2019). Digital 2019: Indonesia. Global Digital Insights, 77. https://doi.org/https://datareportal.com/reports/digital-2019-indonesia.

Yu, C.-S. (2012). Factors Affecting Individuals to Adopt Mobile Banking: Empirical Evidence from the UTAUT Model. Journal of Electronic Commerce Research, 13, 104-121. 